\title{
Korean Version of the Overactive Bladder Symptom Score Questionnaire: Translation and Linguistic Validation
}

\author{
Seong Jin Jeong, Yukio Homma ${ }^{1}$, Seung-June $\mathrm{Oh}^{2}$ \\ Department of Urology, Seoul National University Bundang Hospital, Seongnam, Korea; \\ ${ }^{1}$ Department of Urology, The University of Tokyo Graduate School of Medicine, Tokyo, Japan; \\ ${ }^{2}$ Department of Urology, Seoul National University Hospital, Seoul National University College of Medicine, Seoul, Korea
}

\begin{abstract}
Purpose: The overactive bladder symptom score (OABSS) consists of 4 questions regarding OAB symptoms. The aim of this study was to develop Korean version of the OABSS from the original Japanese version, with subsequent linguistic validation. Methods: Between February and May 2008, the translation and linguistic validation process was performed as follows: a forward translation, reconciliation, backward translation, cognitive debriefing, and final proofreading.

Results: A forward translation from the original version of the OABSS to the Korean language was carried out by 2 native Korean speakers, who were also fluent in Japanese. Reconciliation was made after review of both translations by a panel consisting of both translators and one of the authors. Another bilingual translator who had never seen the original version of the OABSS carried out a translation of the reconciled version back into Japanese, and the original and backward-translated versions were subsequently compared. After discussion of all discrepancies between both versions by the panel, a second Korean version was produced. During cognitive debriefing, 5 outpatients with $\mathrm{OAB}$ reported that each question of the Korean version was significant and appropriate for their symptoms. However, 2 patients said that some parts of the questions or instructions were not clear or were not easy to understand. According to the cognitive debriefing, some words and phrases were revised into more understandable expressions.

Conclusions: A Korean version of the OABSS was developed and linguistic validation was performed. Further studies are needed to assess the reproducibility and validity of the questionnaire in Korean populations.
\end{abstract}

Keywords: Epidemiology; Nocturia; Overactive urinary bladder; Translations

\section{INTRODUCTION}

Overactive bladder $(\mathrm{OAB})$ is characterized by a symptom syndrome of urinary urgency, with or without urgency incontinence, usually with urinary frequency and nocturia, in the absence of infection or other obvious pathologic features [1]. OAB is found at frequencies of 10.0 to $32.6 \%$ among communitydwelling men and women, although the prevalence of $\mathrm{OAB}$ varies according to the target population and definition of OAB. Using current International Continence Society (ICS) definitions of $\mathrm{OAB}[1]$, the prevalence of $\mathrm{OAB}$ symptoms at least "of- ten" has been reported to be $15.8 \%$ and $32.6 \%$ for men and women aged $\geq 40$ years, respectively, in the United States [2], whereas the overall prevalence was $10.0 \%$ and $14.3 \%$, respectively, among Korean counterparts aged $\geq 18$ years [3].

Because $\mathrm{OAB}$ is diagnosed on the basis of subjective symptoms, rather than objective criteria, the patient's perspective is important in the assessment and management of patients with OAB. Therefore, questionnaires that measure the severity of symptoms and their impact on health-related quality of life (HRQOL) play important roles in this disease entity. To date, several questionnaires for the measurement of patient-reported
Corresponding author: Seung-June $\mathrm{Oh}$

Department of Urology, Seoul National University Hospital, Seoul National University College of Medicine, 101 Daehak-ro, Jongno-gu, Seoul, 110-744, Korea

Tel: +82-2-2072-2406 / Fax: +82-2-742-4665 / E-mail address: sjo@snu.ac.kr Submitted: June 23, 2011 / Accepted after revision: August 19, 2011
This is an Open Access article distributed under the terms of the Creative Commons Attribution Non-Commercial License (http://creativecommons.org/licenses/by-nc/3.0/) which permits unrestricted non-commercial use, distribution, and reproduction in any medium, provided the original work is properly cited. 
outcomes of $\mathrm{OAB}$ are available [4,5]. However, each questionnaire has specific weaknesses for application to real practice; namely, some measure the burden of OAB symptoms on daily life rather than the symptoms themselves, some require recording in a micturition diary, and some are not simple to perform in daily practice. The overactive bladder symptom score (OABSS), a new assessment tool for OAB symptoms, was developed and validated in Japanese populations in 2006 by Homma et al. [6]. The OABSS comprises only 4 questions regarding daytime frequency, nocturia, urgency, and urgency incontinence and evaluates relevant symptoms from the patient's viewpoint. At present, the OABSS has just been used in clinical practice, although the majority of patients were Japanese [7-10]. Performance of the OABSS is simple and quick, and a good agreement between OABSS items and the corresponding diary variables was found in a clinical trial with anticholinergics [11]. Therefore, this questionnaire appears to be attractive and beneficial for use in daily practice where a quick and brief estimation of $\mathrm{OAB}$ symptoms and its changes following treatments is required. It is comprised of only 4 questions regarding OAB symptoms, highly sensitive to treatment-related changes of $\mathrm{OAB}$ symptoms $[8,9]$, and demonstrated a fairly good agreement with corresponding diary variables [11].

Objectives of the present study are to develop a Korean version of the OABSS from the original Japanese version, with subsequent linguistic validation in Korean patients with $\mathrm{OAB}$.

\section{MATERIALS AND METHODS}

\section{Original OABSS Questionnaire}

The original Japanese version of the OABSS consists of a total of 4 questions regarding daytime frequency, nocturia, urgency, and urgency incontinence (Appendix 1). Through the weighing of each symptom by use of the influence rate from the epidemiologic database on lower urinary tract symptoms (LUTS), which included 4,570 Japanese residents older than 40 years of age, the relative weight of the maximal score was designated to be 2:3:5:5 for daytime frequency, nocturia, urgency, and urgency incontinence, respectively [6]. The overall score is the sum of the 4 scores, and the diagnostic criteria for OAB are a total OABSS of 3 or more with an urgency score for Question 3 of 2 or more [12]. In the event that the OABSS is used as the standard for the assessment of the severity of $\mathrm{OAB}$, it is recommended that a total score of 5 or less be defined as mild, a score of 6 to 11 as moderate, and a score of 12 or more as severe [13]. In this study, the original Japanese version of the OABSS was translated into Korean, but the English version [6] was used as a reference.

\section{Methodology}

Institutional Review Board approval was not applicable to this study and therefore approval was waived. During the translation, the corresponding author (SJO) directly controlled the overall process of the research. Translation and linguistic validation were carried out between February and May 2008. The overall process was similar to that for translation of the King's Health Questionnaire (KHQ) into Korean, which was performed by $\mathrm{Oh}$ et al. [14], with seven stages, as follows.

\section{Permission for the translation and acquisition of the Japanese version of the OABSS}

The corresponding author (SJO) contacted the owner of this questionnaire (Homma Y.) and obtained permission for the translation and the Japanese version of the OABSS by e-mailing.

\section{Forward translation}

Two translators (YHS [A] and CSY [B]) who did not know each other translated the original version into the Korean language (versions 1.0a and 1.0b, respectively) according to the instructions for forward translation supplied by the corresponding author. Each translator was a native Korean speaker but had lived in Japan for several years, and was therefore fluent in Japanese.

\section{Reconciliation}

On the basis of the two forward translations, reconciliation to form a single forward translation was made after two meetings of a panel consisting of the aforementioned translators and one (SJO) of the authors (version 1.1).

\section{Backward translation}

Another bilingual translator who had never seen the original version of the OABSS carried out a translation of the reconciled version back into the Japanese language, and the original and backward-translated Japanese versions were subsequently compared. When discrepancies between these versions regarding item concepts existed, a new forward translation for the incongruent words and sentences was done. Then, these forward translations were literally backward translated into Japanese. When the panel accepted the new translations, this process was completed and a second Korean version was produced (version 
$1.2)$.

\section{Cognitive debriefing}

Cognitive debriefing interviews with 5 outpatients with $\mathrm{OAB}$ were conducted to test the clarity, cultural adequacy, and comprehension of the wording of the translation and the appropriateness of the translated questions for the patients' symptoms. First, version 1.2 was presented to each patient and the time to complete the questionnaire was assessed. Then, each patient was interviewed in detail regarding what was asked by each question item. The patients provided feedback if they misunderstood the original concept of a question, if they had difficulty in understanding a question, or if a question was vague or not smooth. The authors analyzed the patients' feedback and discussed the expressions to be changed in the translation. A third Korean version (version 1.3) was produced with a report explaining the translation decisions.

\section{Proofreading}

The third version was proofread to check spelling, grammar, and formatting, and the final Korean version of the OABSS was completed (version 1.4).

\section{RESULTS}

\section{Forward Translation and Reconciliation}

"Sukoa Sitsumonhyo" in the Title was translated into "score query" and "jeom-su query" by translator A and translator B, respectively. This was finally reconciled as the "jeom-su questionnaire" in Korean. The "Hindo" in the original version was completely translated into "the number of times" instead of "frequency" because of the possibility of difficulty in understanding of the term "frequency." Another word in the instruction, “Keishou (敬称: a title of honor)," was translated into “mild symptom” because “Keishou (敬称)" was judged to be “Keishou (軽症: mild symptom)" according to the context, and "Keishou (敬称)" was thought to be a mistake in the original version.

Question 1 "Asa okita tokikara nerutoki madeni, nankai kurai nyo o simasitaka" in the original version was reconcilably translated into "How many times did you urinate from waking in the morning until sleeping?" It was thought that the addition of "at night" at the end of the sentence would enhance the understanding of the question. However, because the expression "at night" was not included in the original Japanese version, and backward translation would therefore result in a different ver- sion from the original, the panel decided not to add "at night" to the sentence. In the response option for question 1, "Kai" was translated into "times" by both translators. Although it was thought that "number" was easier to understand than "times," the panel decided to keep the term "times" in the reconciled version to maintain similarity to the expression of question 1. "Yoru netekara" in question 2 was translated into "in sleeping at night" and "through falling asleep at night" by translator A and translator $\mathrm{B}$, respectively. The literal meaning of the original phrase was "from sleeping at night"; however, the panel decided to translate the phrase into "through falling asleep at night" for a more natural expression for Koreans. Question 3 "Kyuni nyoga sitakunari, gamanga mujukasii kotoga arimasitaka" was translated into "How often do you have a sudden desire to urinate, which is difficult to defer?" in the English version of this questionnaire [6]. However, the panel decided to follow the expression of the original Japanese version and translated this into "Have you had difficulty in deferring the urination due to sudden desire to urinate?" "Syuni itkaiyori sukunai" in the response option for Questions 3 and 4 was translated into "A smaller number than one per week" by both translators. The panel decided to use the term "less than" to improve the contrast against the next response option, "Syuni itkai ijou," which was reconciled to "More than once a week." Therefore, this phrase was reconciled to "Less than once a week." However, because it was possible for patients to have trouble understanding or to confuse the exact meaning of "less than," the panel decided to consider the patients' feedback on this phrase during the cognitive debriefing. "Nyo o morasu" in question 4 was literally translated into "get urine out" in the Korean language. Translator A and translator B translated this phrase into "urine leaks" and "let urine flow," respectively. Although the standard language in Korean for this phrase is "wet one's pants," the panel decided to translate it into "urine leaks" because patients may have trouble understanding the exact meaning of "wet one's pants."

\section{Backward Translation}

For most of the questionnaire, the Korean translation was accepted without certain objections because the original Japanese version and the backward translation were almost congruent. There were some differences in Japanese expression; however, the meaning of each sentence between both versions was judged to be almost identical. 


\section{Results of the Debriefing}

The translation was tested by 5 outpatients with OAB. Their ages were diverse, between 30s and 70s, and their level of education was also various, from illiteracy to finishing a college course. Four were women and one was a man; two were employed in economic activities and three were housewives. The patients took an average of 122 seconds (range, 45 to $238 \mathrm{sec}$ onds) to complete the questionnaire. During the in-depth interviews, all of the patients suggested that the questionnaire was meaningful and relevant to their symptoms. Three patients reported that the instructions and questions were generally clear, easy to understand, and easy to complete on their own. One patient felt that the items were somewhat difficult to understand and one said that the items were not easy to understand.

Most of the patients said the word "gwahwaldongsung bangkwang" in the title, which was translated from "Kakatsudou boukou" in the original version, was understandable but awkward in Korean expression. Therefore, this word was adjusted to the real diagnostic term "gwaminsung bangkwang," which is used in Korea. The word "ihaeui," which means "Ikano" in the instruction, was changed to "araeeui," according to a similar suggestion. For question 1, it was suggested that the expression "until sleeping" was vague in determining an exact point of time for patients. The panel decided to add the phrase "at night" to question 1 in order to make the meaning clearer and to enhance continuity with question 2 . In question 2 , "through falling asleep at night" was adjusted to "from sleeping at night" after cognitive debriefing for a more natural expression for Koreans. Some patients suggested that the severity of difficulty in deferring urination be added to the sentence in question 3 . However, because the addition of an expression implying severity would result in limited response to the questionnaire, the panel did not accept this suggestion. In the response option for questions 3 and 4 , most patients did not know the exact meaning of "less than" and "more than." Therefore, these expressions were judged to need some adjustment while the meanings in the original version were maintained: "Less than once a week" to "A smaller number than one per week," "More than once a week" to "Once a week or more," and "More than five times a day" to "Five times a day or more." In question 4, "urine leaks" was judged to be easy to understand by most of the patients; however, a difference from the original version regarding the subject of the sentence was pointed out during proofreading. That is, the subject in "urine leaks" was "urine," whereas the subject in the original Japanese version was a person. Therefore, this phrase was ad- justed to "wet your pants" in order to adhere to the expression of the original version and Korean grammar. The reconciled translations were adjusted after cognitive debriefing and proofreading. The final Korean version of the OABSS was completed (Appendix 2).

\section{DISCUSSION}

OAB symptoms have a negative impact on the HRQOL of patients [15], sexual function [16], and sleep quality [7]. In particular, urgency and urge incontinence, key symptoms of OAB, increase the risk of falls in women aged 40 or older in the community [17]. Because OAB is defined as a symptom syndrome, it may be more useful to conduct a comprehensive assessment of various symptoms rather than an evaluation of individual symptoms. Most studies on clinical trials with OAB patients have assessed the symptom severity and efficacy of treatment according to counting episodes of urgency, incontinence, or frequency [18]. Nowadays, however, a growing concern has been raised regarding the appropriateness of simple counting of symptom episodes for reflecting patient perspectives and perceptions [19]. Therefore, many questionnaires have been developed to reflect the patient's perspective and are currently being used.

However, most of the available questionnaires [4] can be criticized for not evaluating $\mathrm{OAB}$ symptoms as they are, but rather evaluating the bother or effect on daily life resulting from the symptoms [6]. OAB symptoms can affect HRQOL, and, accordingly, evaluation of the impact on HRQOL, which reflects the patient's perspective, rather than the symptoms, may be important. However, a valid tool for describing the symptoms and their severity is also needed because $\mathrm{OAB}$ is a syndrome defined by various symptoms.

The OABSS is a questionnaire with a single total score for quantification of $\mathrm{OAB}$ symptoms, and has been reported to be highly sensitive to treatment-related changes in OAB symptoms in Japanese patients [11]. Previous studies found that the OABSS showed relatively close correlation with the patient perception of bladder condition (PPBC) and OAB-q subscales of HRQOL, with correlation coefficients of 0.36 to 0.57 [20]. In addition, fairly good agreement between OABSS items and the corresponding diary variables was identified at baseline and after an antimuscarinic medication, with particularly high correlations with urgency incontinence and nocturia [11]. From this, it may be possible to infer patient perceptions of $\mathrm{OAB}$ symptoms and 
their bother by the OABSS. Furthermore, owing to its simplicity and dependability, this questionnaire can be an alternative to a bladder diary for assessment of symptoms and efficacy in daily clinical practice. However, the OABSS may not be used for differentiating between $\mathrm{OAB}$ and other diseases causing similar LUTS because of its low specificity for OAB, like other questionnaires.

Still, the OABSS is recommended for use in Japanese populations at this time, because it was developed with the Japanese language and was validated on the basis of Japanese population data only. Use of the OABSS worldwide will require translation into the local language and validation with local data. We developed a Korean version of the OABSS from the original Japanese version, with subsequent linguistic validation in a Korean population with OAB. The authors have had some experience in translating foreign questionnaires for LUTS into the Korean language and validating them linguistically $[14,21,22]$. Translation of the Japanese version of the OABSS was not difficult because the questionnaire consists of only 4 questions, relevant response options, and instructions. In addition, the meanings of the terms used in the original version are generally easy for average people to understand. However, to improve the natural Korean expression, to better enhance understanding of the meaning, and to correct mistakes in wording or grammar, some adjustments of words or phrases were unavoidable during reconciliation of the forward translations and cognitive debriefing.

During the cognitive debriefing, the term "gwahwaldongsung bangkwang," which meant "OAB" in the original version, was adjusted to the real diagnostic term "gwaminsung bangkwang," that is used in Korea to improve the natural expression. In addition, the word "ihaeui," which means "following," in the instruction and the phrase "through falling asleep at night," which means "Yoru netekara," in question 2 were changed to "araeeui (following)" and "from sleeping at night" for the same reason. To enhance understanding of the meaning of the sentence, question 1 was adjusted with the addition of the phrase "at night" to make clearer to patients the point of time and to enhance continuity with question 2 . In addition, the majority of patients suggested that the Korean word for "less than" and "more than" in the response option for questions 3 and 4 might not be easily understood; thus, some phrases were adjusted to make the meaning clearer. Finally, "urine leaks" in question 4 of the reconciled version was different from the original Japanese version regarding the subject of the sentence; thus, this was adjusted to "wet your pants" to adhere to the expression of the original version and Korean grammar.

In general, translation of a questionnaire into a version in another language is not straightforward, and differences in cultures and customs among the populations who use each language have to be considered during translation. The present study has demonstrated that the translation of the Japanese version of the OABSS into the Korean language and the cognitive debriefing process in 5 Korean $\mathrm{OAB}$ patients was performed without major translation difficulties. Adequate conceptual equivalents were demonstrated and accepted by the patients and physicians. However, it is essential to show that these language adaptation is reproducible, valid, and sensitive to treatment-related changes in the next psychometric performance to completely apply this questionnaire to Korean populations in clinical practice.

For more adequate verification of the Korean version, the authors are currently conducting studies on the reproducibility of the OABSS correlation with other measures of OAB symptoms, such as a 3-day micturition diary, International Prostatic Symptom Score, and PPBC and responsiveness to an anticholinergic medication in Korean populations. Information from these studies will be helpful to domestic researchers in their use of the Korean version of the OABSS as a tool for assessment of symptoms in research and clinical practice with domestic OAB patients.

\section{CONFLICT OF INTEREST}

This study was supported by grant No. 06-2008-0380 from Astellas Pharma Korea, Inc.

\section{ACKNOWLEDGEMENT}

Ms. Kyung Eun Choi assisted Japanese transcription.

\section{REFERENCES}

1. Abrams P, Cardozo L, Fall M, Griffiths D, Rosier P, Ulmsten U, et al. The standardisation of terminology of lower urinary tract function: report from the Standardisation Sub-committee of the International Continence Society. Neurourol Urodyn 2002;21:167-78.

2. Coyne KS, Sexton CC, Vats V, Thompson C, Kopp ZS, Milsom I. National community prevalence of overactive bladder in the United States stratified by sex and age. Urology 2011;77:1081-7.

3. Lee YS, Lee KS, Jung JH, Han DH, Oh SJ, Seo JT, et al. Prevalence 
of overactive bladder, urinary incontinence, and lower urinary tract symptoms: results of Korean EPIC study. World J Urol 2011;29:18590.

4. Matza LS, Thompson CL, Krasnow J, Brewster-Jordan J, Zyczynski T, Coyne KS. Test-retest reliability of four questionnaires for patients with overactive bladder: the overactive bladder questionnaire (OAB-q), patient perception of bladder condition (PPBC), urgency questionnaire (UQ), and the primary $\mathrm{OAB}$ symptom questionnaire (POSQ). Neurourol Urodyn 2005;24:215-25.

5. Zinner N, Harnett M, Sabounjian L, Sandage B Jr, Dmochowski R, Staskin D. The overactive bladder-symptom composite score: a composite symptom score of toilet voids, urgency severity and urge urinary incontinence in patients with overactive bladder. J Urol 2005;173:1639-43.

6. Homma Y, Yoshida M, Seki N, Yokoyama O, Kakizaki H, Gotoh M, et al. Symptom assessment tool for overactive bladder syndrome-overactive bladder symptom score. Urology 2006;68:318-23.

7. Tsujimura A, Takao T, Miyagawa Y, Yamamoto K, Fukuhara S, Nakayama J, et al. Urgency is an independent factor for sleep disturbance in men with obstructive sleep apnea. Urology 2010;76:967-70.

8. Tanaka Y, Masumori N, Tsukamoto T. Urodynamic effects of solifenacin in untreated female patients with symptomatic overactive bladder. Int J Urol 2010;17:796-800.

9. Watanabe M, Yamanishi T, Honda M, Sakakibara R, Uchiyama T, Yoshida K. Efficacy of extended-release tolterodine for the treatment of neurogenic detrusor overactivity and/or low-compliance bladder. Int J Urol 2010;17:931-6.

10. Gotoh M, Yokoyama O, Nishizawa O; Japanese Propiverine Study Group. Propiverine hydrochloride in Japanese patients with overactive bladder: a randomized, double-blind, placebo-controlled trial. Int J Urol 2011;18:365-73.

11. Homma Y, Kakizaki H, Yamaguchi O, Yamanishi T, Nishizawa O, Yokoyama $\mathrm{O}$, et al. Assessment of overactive bladder symptoms: comparison of 3-day bladder diary and the overactive bladder symptoms score. Urology 2011;77:60-4.

12. Yamaguchi O, Nishizawa O, Takeda M, Yokoyama O, Homma Y, Kakizaki H, et al. Clinical guidelines for overactive bladder. Int J
Urol 2009;16:126-42.

13. Homma Y, Yoshida M, Obara K, Seki N, Yamaguchi O. Development and validity of the Overactive Bladder Symptom Score (OABSS). Jpn J Urol 2005;96:182.

14. Oh SJ, Park HG, Paick SH, Park WH, Choo MS. Translation and linguistic validation of Korean version of the King's Health Questionnaire Instrument. Korean J Urol 2005;46:438-50.

15. Coyne KS, Sexton CC, Kopp ZS, Ebel-Bitoun C, Milsom I, Chapple C. The impact of overactive bladder on mental health, work productivity and health-related quality of life in the UK and Sweden: results from EpiLUTS. BJU Int 2011 Mar 3 [Epub]. DOI: 10.1111/ j.1464-410X.2010.10013.x.

16. Heidler S, Mert C, Wehrberger C, Temml C, Ponholzer A, Rauchenwald $M$, et al. Impact of overactive bladder symptoms on sexuality in both sexes. Urol Int 2010;85:443-6.

17. Moon SJ, Kim YT, Lee TY, Moon H, Kim MJ, Kim SA, et al. The influence of an overactive bladder on falling: a study of females aged 40 and older in the community. Int Neurourol J 2011;15:41-7.

18. Novara G, Galfano A, Secco S, D’Elia C, Cavalleri S, Ficarra V, et al. A systematic review and meta-analysis of randomized controlled trials with antimuscarinic drugs for overactive bladder. Eur Urol 2008;54:740-63.

19. Chapple CR, Artibani W, Cardozo LD, Castro-Diaz D, Craggs M, Haab F, et al. The role of urinary urgency and its measurement in the overactive bladder symptom syndrome: current concepts and future prospects. BJU Int 2005;95:335-40.

20. Homma Y, Gotoh M. Symptom severity and patient perceptions in overactive bladder: how are they related? BJU Int 2009;104:968-72.

21. Oh SJ, Park HG, Lim SH, Hong SK, Kim SW, Kim HH, et al. Translation and linguistic validation of Korean version of the Incontinence quality of life(I-QoL) instrument. J Korean Continence Soc 2002;6:10-23.

22. Son HC, Jung YJ, Chang JS, Kim SH, Hong SK, Oh SJ, et al. Translation and linguistic validation of the Korean version of the pelvic pain and urgency/frequency patient symptom scale. Int Neurourol J 2010;14:112-21. 
Appendix 1. Original Japanese version of the Overactive Bladder Symptom Score questionnaire

\section{過活動膀胱症状スコア質問票 \\ (overactive bladder symptom score: OABSS)}

以下の症状がどれくらいの頻度でありましたか。この 1 週間のあなたの状態に最も近いものを、1つだけ選んで、 点数の数字を○で囲んで下さい。

\begin{tabular}{|c|c|c|c|}
\hline 質 問 & 症 状 & 頻 度 & 点 数 \\
\hline \multirow[t]{3}{*}{1} & 朝起きた時から寝る時までに、何回くらい尿をしましたか & 7回以下 & 0 \\
\hline & & 8〜14回 & 1 \\
\hline & & 15回以上 & 2 \\
\hline \multirow[t]{4}{*}{2} & 夜寝てから朝起きるまでに、何回くらい尿をするために起きましたか & 0回 & 0 \\
\hline & & 1回 & 1 \\
\hline & & 2回 & 2 \\
\hline & & 3回以上 & 3 \\
\hline \multirow[t]{6}{*}{3} & 急に尿がしたくなり、我慢が難しいことがありましたか & なし & 0 \\
\hline & & 週に1回より少ない & 1 \\
\hline & & 週に1回以上 & 2 \\
\hline & & 1日1回くらい & 3 \\
\hline & & 1日2～4回 & 4 \\
\hline & & 1日5回以上 & 5 \\
\hline \multirow[t]{6}{*}{4} & 急に尿がしたくなり、我慢できずに尿をもらすことがありましたか & なし & 0 \\
\hline & & 週に1回より少ない & 1 \\
\hline & & 週に1回以上 & 2 \\
\hline & & 1日1回くらい & 3 \\
\hline & & 1日2～4回 & 4 \\
\hline & & 1日5回以上 & 5 \\
\hline \multicolumn{2}{|c|}{ 合計点数(OABSS) } & & 点 \\
\hline
\end{tabular}

「質問3のスコアが2点以上、かつ、合計スコアが3点以上」を診断要件とする。 合計 スコアが5点以下を敬称、6から11点を中等症、12点以上を重症とする。 
Appendix 2. Korean version of the Overactive Bladder Symptom Score questionnaire

$\begin{array}{ll}\text { 등록번호: } & \\ \text { 이 름: } & \\ \text { 날 짜: 년 눨﹎일 }\end{array}$

\section{OABSS (과민성방광 증상 점수 설문지)}

아래의 증상이 어느 정도의 횟수로 있었습니까?

최근 1 주일간 당신의 상태에 가장 가까운 것을 하나만 골라서 점수의 숫자에 $\mathrm{O}$ 표 해주세요.

\begin{tabular}{|c|c|c|c|}
\hline 질 문 & 증 상 & 횟 수 & 점 수 \\
\hline \multirow[t]{3}{*}{1} & 아침에 일어나서 밤에 자기 전까지 몇 회 정도 소변을 보셨습니까? & 7회 이하 & 0 \\
\hline & & 8〜14회 & 1 \\
\hline & & 15 회 이상 & 2 \\
\hline \multirow[t]{4}{*}{2} & 밤에 잠든 후부터 아침에 일어날 때까지 소변을 보기 위해 & 0 회 & 0 \\
\hline & 몇 회나 일어나셨습니까? & 1 회 & 1 \\
\hline & & 2회 & 2 \\
\hline & & 3회 이상 & 3 \\
\hline \multirow[t]{6}{*}{3} & 갑자기 소변이 마려워 참기 힘들었던 적이 있었습니까? & 없음 & 0 \\
\hline & & 일주일에 1회 보다는 적음 & 1 \\
\hline & & 일주일에 1회 또는 그 이상 & 2 \\
\hline & & 1일 1회 정도 & 3 \\
\hline & & 1일 2 4회 & 4 \\
\hline & & 1일 5회 또는 그 이상 & 5 \\
\hline \multirow[t]{6}{*}{4} & 갑자기 소변이 마려워서 참지 못하고 소변을 지린 적이 있었습니까? & 없음 & 0 \\
\hline & & 일주일에 1 회 보다는 적음 & 1 \\
\hline & & 일주일에 1회 또는 그 이상 & 2 \\
\hline & & 1 일 1 회 정도 & 3 \\
\hline & & 1일 2 4회 & 4 \\
\hline & & 1 일 5 회 또는 그 이상 & 5 \\
\hline & 합계점수 & & 점 \\
\hline
\end{tabular}

「질문 3 의 점수가 2 점 이상이면서 총점이 3 점 이상』 을 진단요건으로 한다. 총점이 5 점 이하를 경증, 6 점에서 11 점을 중등증, 12 점 이상을 중증 으로 한다. 